\title{
Interconnectivity of Marriage, Sexuality and Streedharma: Reflections through the Minor Female Characters of the Mahabharata
}

\author{
Praggnaparamita Biswas \\ Asiatic Society, Kolkata.Email: praggnaparamitabi@gmail.com
}

\begin{abstract}
Mahabharata, the outstanding sacred text of India, is a preamble to the Indian social philosophy. This prehensile text encompasses all sorts of contemporary feminist agendas like gender discrimination, sexuality, female body politics, women disposition, marriage, kinship and so on. Dharma, being the focal point of Mahabharata, acts as a catalyst in outlining the epical structure of this sacred text. Anthropological elements like marriage, sexuality, lineage, motherhood etc. somehow maintain interlink with dharma, particularly with the streedharma. Thus, the symbiotic relationship of sexuality, marriage and streedharma helps in formulating the code of conduct for women of that era. The present paper intends to analyze the aforementioned anthropological issues through the lives of minor female characters who by dint of their courage and dedication change the track of the epic. Though the epical minor females are somehow nugatory or unrecognized due to politics of gender politics, but they are the most viable for situational decision of royal as well as epical design. Therefore this paper tries to justify their strong epical presence and hidden epical politics bestow upon them.
\end{abstract}

Key words: Sexuality, Streedharma, Gender politics, Polyandry, Niyoga pratha, Reproductivity.

Mahabharata, the outstanding sacred text of India, is a preamble to the Indian social philosophy. The epic being a social drama opens and connects the maze of Indian society. This prehensile text encompasses all sorts of contemporary feminist agendas like gender discrimination, sexuality, female body politics, women disposition, marriage, kinship and so on. Indian people's dependency upon it to formulate the socio-cultural punctilio is amazing. Actually they seek the spiritual blessing before the auspicious social occasions. Their entrenched belief on the path of dharma purveys this. Being the focal point of Mahabharata, dharma acts as a catalyst in outlining the epical structure of this sacred text. The ubiquitous presence of dharma throughout the text serves as a springboard for comprehending the social, political, religious and cultural aspects of this great epic by providing guidelines to the readers for grasping the causal relation of so many incidents recorded by the poet in the Mahabharata. Social elements like marriage, sexuality, motherhood etc. somehow maintain interlink with dharma, particularly with the streedharma. Thus, the symbiotic relationship of sexuality, marriage and streedharma helps in formulating the code of conduct for women of that era. In the epic we get a galaxy of female characters like Draupadi, Kunti, Gandhari who are prominent forever in the text for their strong, intelligent, feminine personality. But apart from them, we find a host of peripheral characters who are illuminating through their own deeds, though they always stay away from focus. These neglected

(c) AesthetixMS 2016. This Open Access article is published under a Creative Commons Attribution Non-Commercial 4.0 International License (http://creativecommons.org/licenses/by-nc/4.0/), which permits non-commercial re-use, distribution, and reproduction in any medium, provided the original work is properly cited. For citation use the DOI. For commercial re-use, please contact aesthetixms@gmail.com. 
but prominent minor female characters sacrifice their lives and femininity for the sake of streedharma, but the poet does not think it necessary to use enough ink for them.

India, the treasury of two great epics the Ramayana and the Mahabharata depends very much on these sacred texts for formulating the social customs of quotidian lives. In our daily life, Indian womenfolk still remember the names of Pancha Kanya of Mahabharata and recite them as hymns in the morning for removal of all sins from our life. Though the author of Mahabharata Vyasadeva unveils his apathy while portraying the numerous female characters, but people feel sympathy and empathy for them. These royal ladies not only embody the ideal womanhood for Indian female but sing the paean of femininity also. The major female figures like Draupadi, Kunti and Gandhari set examples of a model wife and mother; still, they are not flawless in maintaining their personal and public life. Like average people, they also face the thunder of male biased society. In spite of their royal birth and dominance, their feminine value and respect level go down to the dust either for their epical fate or divine bane. Thus, they become a puppet in the hands of their male counterparts. No spirit of personality, no spirit of consciousness of womanhood was imbibed in them by the poet by whom they could challenge the unkindness of the wrong doers. They simply had to reconcile to their ill-fate. In the name of preserving the dharma, they are only exploited. The only solace to us is that these leading ladies of the epic get much attention of the poet and the readers. But, the big question mark is put on the role of minor female characters of the Mahabharata. It astonishes us that the same amount of chastity, obedience, sacrifice cannot enable them to deserve the same prestige the main characters enjoy in the eyes of masses. The practice of dharma and its application discriminates them unfairly. This previews the dichotomous face of dharma in the Mahabharata.

An overview of the great epics of the world projects a despairing picture of women in terms of religious attitude. Most of the sacred texts of India exude an anti-feministic mentality. The Vedas, the Upanishadas and the Smriti of Manu display mixed feelings about women: the Vedas only highlight the dark side of women, Upanishadas define the women as the child-bearing machine while Manu depicts them as both virtuous and vicious. But it is in the Anusasan Parvan of the Mahabharata where the poet utters the most scandalous remark: "women are the source of all evils... poisonous snake, the sharp edge of a sword will not be collectively equal to a woman." (XII.283). It is intriguing that what makes the poet make such scandalous comment on women when the entire epic deals with countless female characters that show enough potency for maneuvering the royal domesticity. Actually patriarchal worldview of the epic is responsible for such acrimony against the womenfolk. About the disposition of women in the Mahabharata, we may not get a positive picture. In spite of their whole hearted devotion to husband and kinsman, the poet portrays them uncharitably. To generalize the view, he picks the quality of infidelity, viciousness, fickleness and lasciviousness etc. in many women characters. The virtue of loyalty and modesty is unknown to them. In the question of virtue and religion, they are totally confused. Because of all these supposed negative qualities of women, they become the origin of all sins and evils. So, dharma viz. religion unfolds too much misogynistic demeanour towards women. For this, scholar Gross once comment: “are the world's religions inevitably sexist?" May be the answer is positive as religious misogyny is therefore but one manifestation of the extremely widespread war of sexes. And it is very surprising for us that in every great epic we find a woman being responsible for the destructive war. The great epics like the Ramayana, the Mahabharata, and the Odyssey encounter the battles for ladies - Sita, Draupadi, Helen respectively. In fact, the institutionalization of patriarchy for their own purpose, utilize the women as a subject in the name of religion. 


\section{II}

Among the so many sub-categories of dharma, the idea of streedharma conceptualizes the crux of Mahabharata. Some scholars describe the epic Mahabharata as "a unique reprisal of matrihumiliation". So, the pictograph of Draupadi's sexual harassment before the Puru elders at royal court somehow sows the seed of the 'crusade' at Kurushetra. It was the prophecy at the very moment of her birth that the Kuru clan will be wiped out for Draupadi and its starting point was the dice playing at Kuru royal court. However, the humiliation of Draupadi at gambling holds an endless controversy till today and it enhances the fratricidal war of Kurushetra. As Draupadi, the leading Pandava lady of Mahabharata has encountered the highest dishonour of femininity in spite of her loyalty to husbands and streedharma, so the question of relevance of streedharma as well as dharma comes to focus.

On defining the streedharma of Mahabharata the conversation between Draupadi and Satyabhama signifies a lot. Asking by the question about how to keep the affection and obedience of her husband and suggest a variety of means, such as spells and sacrifices, Draupadi condemns the use of deceitful manipulations in marriage and describes her own behaviour in relationship to her husbands, their retinue and her mother-in-law. She stresses that her methods of actions in dealing the business of household chiefly based on truthfulness, not any kind of spell at all. An initial reading of the dialogue would reveal a single gender ideology: the servile attitude of Draupadi and her utter devotion to pativrata as she says "to live under husband's protection is the sanatana dharma for women. Husband is god, he is salvation for women and he is the only refuge". In her domestic chores, she always prefers to do her personal activities like bathing, eating and sleeping after her husbands and maintains obedience at the time of speaking. Actually, Draupadi's royal born and brought up teaches her the basic power dynamics between men and women and her own sense of power and agency within a given situation aids her to tackle all with single handedly. She is constructing a dialogic self - a loosely connected set of voices in dialogic relation to each other.

Actually Satyabhama, in some kidding mood hints at the necromancy for controlling the husband but Draupadi's firm reply to her was that her conduct ought to be truth, not asat or dishonest. She comments that the path of dishonesty, non-truthful conduct, is a difficult one to praise. Her insight displays the notion of 'balance of power' in a spousal relationship. Her rejection to any kind of recitation of mantra and application of magical roots proves the fact that she does not like to practice the serpentine nature for managing the household to keep permanent happiness in home because any deceitful activity of women within the domestic arena incites fear in man and contaminate the sanctity of domesticity. Apart from the supervision of the household, she also well informed about the hospitality of guests and her financial mastery over the treasury of the palace shows her keen comprehension of power balance in the socio-economic sphere of life. In case of Kunti, she also proves her awareness of the need for acknowledging the power balance between two female members of a same house. The MIL-DIL business between them is a symbolic way of 'sharing experience' in terms of social consciousness-raising. Indian playwright Poile Sengupta dramatizes the MIL-DIL relationship in Inner Laws which is the modern adaptation of the epic.

The discussion of streedharma along with its two associate topics like sexuality and marriage in Mahabharata always draws much attention from scholars. Woman as subject forms the centre of a triangular relationship of sexuality, marriage and streedharma. Man and woman as social beings 
tie the wedlock under the social institution of marriage in which sexuality plays a pivotal role for shaping the structure of a family and for making a pleasant household an ideal wife should have the lesson of streedharma. So, we can get a logical inseparable interconnectivity among these three. As the aim of this paper is to interpret this relationship through minor female characters of Mahabharata, so the paper will develop the characters like Hirimba, Satyabhama, Satyavati, Amibka, Ambalika and so on. May be Draupadi as a role model overcomes the others, but these minor characters are also prominent by dint of their virtue and morality. Again, it is not possible to design a discussion by shunning the mode of comparison of Draupadi with others. So, she frequently appears in a comparative way.

\section{III}

Marriage as a social institution plays a vital role in the epic Mahabharata. Genealogy of royal pedigree gives massive importance to it. Marriage describes a sacred bond between man and woman. The chief aim of the marriage is to keep the chain of creation of human being unbroken by reproducing progeny. The system of marriage has been prevailing in society in order to keep the social order morally and ethically superior one, within a restricted sexual union. The biological necessity of marriage is for motherhood. In terms of matrimony, the poet introduces few novel ideas for the well being of royal family. Many of these novelties create utter surprise to us and also give a clear hint for scientific evolution. As we have already stated that marriage and streedharma are interrelated and the analysis of streedharma from matrimonial point of view is essential in case of Mahabharata.

A close scrutiny of Mahabharata provides us the five different kinds of marriages of which brahma, prajapati and gandharva systems consider to be the fair and just. The children of these marriages are lawful for performing the social and religious rituals of the family. Most of the royal and common marriages of the epic belong to it. But, Mahabharata is the store-house of rare incidents, so we must point out the exceptional cases and investigate the mystery behind it as each of these miraculous happenings has its own moral and epical groundings acknowledged by the poet.

The introduction of swayamvara as a special marriage system, in which the girl herself selects her husband in an open contest of the suitors, is one of the remarkable events of Mahabharata. Apart from the political purport, the poet implicitly keeps a hint in this process. To exemplify this epical view, we may cite the swayamvaras of Draupadi and Damayanti. In case of Draupadi, the concept of swaymvara highlights a critical issue. Though king Drupada desires an alliance from the Pandavas, but the concurrent political turmoil was not favourable for the Pandavas. The compulsion of forest exile makes the situation more intrinsic for them and in this condition the participation in marriage may not be suitable for them. But the system of swayamvara is an open contest for choosing bridegroom in which the Darwinian idea of the 'survival for the fittest' seems as the best policy for the contestants to achieve the goal. Arjuna, the third Panadavas by piercing the target, had conquered the bride Draupadi.

Another remarkable perspective of wedding in the epic is obviously the technique of 'niyoga pratha', a custom of levirate marriage of a special provision in the sexual ethics. In this process, a wife allows to obtain child through the instrument of another man with the permission of her husband. This copulation is only applicable if the husband is deceased or infertile or somehow incapable in producing the inheritor for reviewing their lineages. Under the social law such children are legitimate and no stigma of immorality or licentiousness has been imposed to the 
mother. To impregnate the wife, the 'niyoga' man should be the brother or near relative of husband enriched with reputed mental and spiritual splendor and high ascetic accomplishments. Ms. Arti Dhand points out that the practice of niyoga is designed to realize a socially recognized need for people to produce children within the same partiline, perhaps out of concerns for inheritance and property issues. In this respect Mahabharata critic A.N. Bhattacharya puts a logical argument on behalf of right selection of sexual partner for reproduction. It is scientifically proved that better stocks are produced by superior breeds. British dramatist Bernard Shaw also advocates this Nietzschian idea in his socialistic play Man and Superman where the Shavian heroine Ann wishes to marry the superman Tanner for bright future generation. The same is applicable for Kunti who proves that by getting heavenly sons like Yudhistir, Bhima and Arjuna, the interventions of celestial father Dharma, Bayu and Indra were highly relevant. By mothering such brilliant progeny for human welfare, she performs the virtue and in this respect her reproductions in out of wedlock is under relaxation. In selecting the copulating partner in niyoga, the woman herself has lees verbal right. They function as passive medium for the will of husband and affinal kin and primarily viewed as the means for the patriarchal family to achieve its own ends. The woman seems as a field of harvest in which husband's family plants the seeds for the protection of its own family tree. Thus 'niyoga' performs under the circumstances in which woman neither has any share in decision making or choice for selecting partner.

In performing the 'niyoga' though it seems an apparent violation of the ethic of sexual fidelity to one's husband and the impurity of chastity comes to the question. But in Mahabharata, the 'niyoga' as an exceptional system of reproductivity and the performance of streedharma bears a subtle pragmatic political view. We know that the birth of the Pandavas and their fathers Dhritarastra and Pandu were through the fruitful application of this procedure. But the process varies in two different spheres. Firstly if we take the birth of Pandavas, we can notice some advantageous verdict in favour of Kunti as she shows her own choice in selecting her sexual partners of 'niyoga'. Though Kunti is initially not ready to involve herself in it, but later, conceived by Pandu's instructive plea with a sinister twisted statement " $a$ wife who is directed by her husband to conceive a child but refuses, shall incur the same evil as one who aborts a child"(Dhand, 2004,41) has to yield herself into the hand of patriarchal pressure. On account of Kunti's counternarrative, Pandu cleverly gives her the reminder that a husband's instruction to his wife, whether righteous or unrighteous, always acts as a non-debatable and non-doubtable one and the wife should pay reverence to her husband by doing it immediately. Thus, she can elevate herself to the zenith of pativrata. And therefore, Kunti in terms of streedharma must obey her husband and share her bed with four divine gods for producing heroic children. These divine children give an extraordinary grandeur to her femininity and she is never socially accused of adultery.

In contrast to this, through the birth of Dhritarsatra and Pandu, we can get a different picture. Dhritarsatra and Pandu, the offsprings of Vyasa by applying the 'niyoga' custom on Ambika and Ambalika respectectively, have occurred with the permission of Satyavati. But, unfortunately, Ambika and Ambalika unlike Kunti, had no choice to select their partners. The combined decision of Satyavati and Bhisma was the be-all and end-all of their lives. But due to the compulsion from the nuptial family, they had to consummate with the smelly, ugly looking brother-in-law Vyasa and as a consequence of it, they produce the blind and discoloured sons who will be doubly cursed for their matrilineal and personal flaws. Unlike Kunti, these two sisters were not blessed and didn't have any magical formula to get divine lovers and sons, rather they became the victim of curse of Vyasa. In spite of rearing the dharma and streedharma to the cause of marital family, they are still deprived and exploited at the hand of destiny and marginalized in the epical view. This comparative study of Kunti and two Kashi sisters show a quintessential 
partiality of dharma. The distinctive face of leading majority and minority appears very prominently. Kunti as one of the leading ladies of Mahabharata, gets the authoritative favour of divine boon, for procreation but on the other hand Ambalika and Ambika as peripheral characters of the epic, gets only the authoritative curse, negligence and sufferings.

In terms of matrimony, the poet also highlights the epical attitude towards the system of intersect marriages in Mahabharata. The practices of inter-sect marriages of Bhima to Hirimba and Arjuna to Ulupi display the innovative nature of the author. The respective brides Hirimba and Ulupi are rakshas by genesis and serpent by origin. So, they are different in culture, creed, habit and customs, but not in the physical appearance. Actually, cultural heritage is an important factor in marriage. So, people may have some misconception about these intersect marriages of Mahabharata. But, a closer scrutiny of these weddings corroborates the very core idea of femininity. For example, Hirimba, though a representative of 'rakshas joni', but her eternal feminine nature and devotion to husband Bhima is more potent than rakshasi characteristics. Her nature justifies that dharma for woman means the transformation of the role of feminine energy. In performance of streedharma, Hirimba may be an iconic bride of the epic. In her lifetime, she has only a single scope to spend a few days for enjoying the bliss of marital life with Bhima. After that, according to the pre-condition of marriage, she has to leave him forever immediately with the birth of their son Ghatotkacha. Her only way of living is through reminiscence, down the memory lane and endless waiting. She will be memorable in Mahabharata for her sacrificial and devotional nature as by getting married with Bhima, she has been discarded and alienated from her own caste. In spite of her wedlock to Bhima, she became an outcast. It appears that she has been used instrumentally by Vyasa to produce a warrior-cum-protector son for politics of warfare. With her utmost femininity she never wants to be a chief queen, but only an ordinary wife full of love, compassion and emotion. But she was highly concerned about her own desire and has the caste conflict of man-demon. So, her unfathomable depth of feelings is praiseworthy. By investigating this quality, she is able to exalt her streedharma to an apogee. She embodies the typical Indian womanhood as the question of selfhood, individuality does not a matter at all to her. She tries to exercise the cult of streedharma through supreme suffering of separation. Her voluntary exile gives her a pleasure for nurturing the precious moments of their romantic past.

Significantly, in Mahabharata we found the references of an antithetical image of marriages namely polygamy and polyandry. The trait of polygamy almost becomes a social convention in the text of this epic. Marrying more than a wife was legally and morally accepted by that society. The critical explanation of it may be political and generational reasons. In practicing the polygamy, the possibility of extended family relationships can be enormous and it would help to reduce the rivalry among the rulers because of that bonding. Again, in those days the obsession for son to keep the lineage unbroken was very prominent. In this regard, if someone has failed to get a son from the first marriage, then there would be enough probability to procreate next generation for continuing the paternal heredity through the polygamous system of marriage. We can locate the frequent citations of polygamy in cases of Pandu, Arjuna, Krishna, Bhima to fulfill the political and generational causes. But surprisingly enough, we only trace out a single example of polyandry in the case of Draupadi's marriage. Actually to conceptualize the two different homogenous ideas is so problematic in terms of dharma, that it puts so many contradictory questions before us. While polygamy refers to the exercise of having more than one wife at the same time, polyandry, on the other hand is supposed to enable a wife to be shared among several husbands. But most probably the poet can be able to wrap up this polygamy/andry with that of dharma in the sense, that both of these are engaged to do the same sacred deed of producing son for wellbeing of the clans. If the first one i.e. polygamy has the quantity, then the later one i.e. polyandry has the 
quality. So, the authoritative debate of these two distinctive aspects of marriages is too subtle to solving the puzzle. But, if we interpret it from the biological point of view, then we can find that "the feminine structure is so built that it is difficult to bear by a woman more than one foetus" and in this respect the act of polyandry is not immoral. A. N. Jani flags out the ethnological, social, and economical reason for inventing the system of polyandry. The custom of polyandry was prevalent in ancient India and still it is a part of some tribal community of the Todas of the Nilgiri range. It seems to have originated out of social necessity in those regions where the number of females was less than that of males. From economical point of view, this process helps to accumulate the family wealth in one place. Eventually in Mahabharata, an irresistible passion due to Draupadi's extraordinary beauty may be a stimulus of fatal fratricide among them. So, to shun off such disharmony, Yudhisthira's foresight prefers to obey the mother Kunti's command to enjoy the 'alms' Draupadi jointly. All these causes explicate the erudite vision of Yudhisthira to advocate the legality of polyandry. Hence, we may say that polygamy/andry of Mahabharata is a moral, virtuous issue to achieve the bliss of son. Thus, the exercise of streedharma will be intact in this process.

IV

The agenda of sexuality may be found implicitly or explicitly everywhere in Mahabharata. Sexuality in the epic serves as an apparatus for formulating the socio-cultural structure of a particular time. The process of sexuality as a biological phenomenon is central to the creation of human being. The birth of child without sexual intercourse is impossible. This clearly indicates that both male and female organs engaged in orgasm are not objects of apathy as the displaying of these organs arouses a sort of hormonal excitement and sexual appeal in people. So, desire of sexuality in opposite sex is common forever. The epic depicts the multiple pictures of different copulations in which the very truth of human nature is disclosed that no man can bear or live without it. It is natural and in-born quality of man. It is neither a filthy nor an untouched one but there should be some restrictions for it. It may be gods or renowned sages with uncommon spiritual power, but to defy the sexual impulse is more difficult task than meditation itself. The sexual weakness of mortal beings is therefore a matter of hindrance in the path of glory. Again it puts forth the question of morality before us.

Mahabharata through its plethora of narratives gives a remarkable panorama of human sexuality. There is no clue of sexual freedom of women in the epic; rather the cultural taboos were imposed upon the mating pattern. The act of bonking for them was strictly restricted to their husband only. The sense of chastity and fidelity looms anxiety in case of deviating the norms of sexuality. The sexual autonomy of women was regulated by patriarchal imperious. But the overview of the epic-text generalizes that women love to be sexually free. Surprisingly, hardly any example of female adultery can be found in the epic. But Mahabharata never provides transparency whether the strictures on women's sexuality should be read as constructive or destructive. Thus, epical attitude toward female sexuality is almost quasi-fictive.

The patriarchal control over women's sexuality - the choice of partner, reproductive facility is subject of manipulation of husband. This is the target of ordering and disciplining machinations of society. The popular myth of Indra's sin of brahmanicide narrates the story of women's magnificent tendency towards sexuality as Brahma decides to lessen the burden of sin of Indra by distributing it to the celestial nymphs, the apsaras. And Mahabharata primarily talks about the tale of king Puru and apsara Urvashi, the ancestral parents of the Kuru dynasty. So, the origin of 
the royal family and the birth of semi-divine author Vyasadeva of the epic are both the resultants of unbridled sexuality. Due to blasphemous nature of female sexuality, it always encounters strong lambaste of patriarchy, but scholars should be honest and unbiased to dig the reality of it.

In Mahabharata, female sexuality shows an ambiguous quality. It is exploited and exalted on the one hand, and at the same time, it is also dangerous and potentially sinful. The linkage of women, sex and female corpus mechanism and peccadillo is thus made explicit. Along with its fertility, living giving quality, female sexuality thus proves its powerful and dangerous aspects. But the epic not only depicts the positive or negative picture of female sexuality, rather it portrays the male outlook to it. So many events of Mahabharata certify the promiscuous nature of men who may be sage, ascetics and so on. Unlike marriage, Mahabharata, in terms of male sexuality never shows any rigidity; rather it prefers the free mixing of man-woman. Even to gratify the sexual appease, the class or caste never appears as an impediment. As a consequence of it we get the instances of the union of the divine people with that of earth people. This proves that sexual desire is not monopoly of a certain class. The intensity of sex impulsiveness destroys the least sense of moral code and conduct of society. In most of the cases there remain a power politics behind this unwanted or uncontrolled sexuality.

In defining the sexuality of Mahabharata, the role of apsaras holds much attention. In general view, these apsaras are the divine prostitutes who are relatively sexually autonomous. They are the only anthropomorphized beings who consort with multiple sexual partners. Critics of Mahabharata recognize them as the matriarch goddess of Hindu mythology. The primary function of apsara is to rouse male passions. In the epic we trace some common features of them: being beautiful seductresses, they lure ascetics away from their paths of meditation by dint of their libidinous gestures and stripteases. As femme fatale, they represent the apex of the heavenly delights of sensuality. In quoting Ms. Arti Dhand:

"Apsaras are the recipients of sinfulness precisely because they occupy this visceral mythological space. They embody sexuality, its attractions and its dangers, hence they are always a suspicious category, always potentially errant and beyond control." (Dhand, 200o, 188)

Ironically, all these apsaras lives in heaven in aegis of god Indra who transmitted his own vice of bhramancide into them. To perpetuate his kingdom, he makes a trick in which these apsaras and sages become the users and losers respectively of his divine power appetite. By taking the advantage of sexual weakness of mortal men, he forcefully send the apsaras to jeopardize the concentrations of the great sages who at that time deeply engage in some contemplation for achieving some spirituality which may be threatened to maintaining the divinity of gods. These heavenly prostitutes have the compulsion to obey the bossing command for divine welfare. Envision of beautiful nymphs with shaft of cupid makes them love-lorn. Being, love-sick, they lost their mind and engage themselves into consummations. The tragedy of these events lays in the fact that they even can't see the faces of their new born child. So, they were entirely deprived from the bliss of motherhood. These apsaras actually act as the instrumental one to fulfilling the political purpose of gods. So we may say that apsaras' symbolic presence in the epic epitomizes the unbridled carnal desire of human beings. The supervision of Indra of heavenly brothel reminds us of the masculine attitude towards sexual politics.

The earthly men's union with apsaras in Mahabharata produces a group of epical characters like Shakuntala, Drona, Kripa and so on. The Bharata mother Shakuntala, a half-celestial beautiful lash is the illegitimate child of king-sage Viswamitra and the divine pros Menka. Manipulating by Indra's command Menka makes a successful attempt of debauch the sage from meditation. 
Captivating by her beauty, Viswamitra totally moved away by the spell of love and enjoy the sexual pleasure and the birth of the girl child Shakuntala is the offspring of this conjugal relationship. Again the birth of Drona and Kripa from the falling semen of the respective sage Bharadwaj and Saradwan into the apsara genital of Ghritachi and Janapadi signifies the sexual craving of worldly men.

But it is not only the apsaras' self-approach to sages, but sometime sage himself can't shun off the sex appeal of earthly maiden. The day light copulation of the sage Parasar and the fisherwoman Satyavati exemplifies this truth. Overwhelmed by the beauty of young maiden Satyavati, the great sage Parasar requests her to appease his erotic passion. But being a virgin, she denies the sagely demand of Parasar by excusing that she is still under supervision of her father. But the physical demand of sage was so strong then, that he co-habit her on the agreement of reinstate of virginity after intercourse. The semi-divine author Vyasdeva is the child born out of it. In this episode, we get forcible ravishment of sexuality. Satyavati's consent for it was just fire out. Her prerogative on femininity or womanhood devalues before the sexual urge of a great sage. His manhood seems more potential to consolidate his masculine clam. The recurring of male controlling over female sexuality comes to focus again.

Another dimension of sexuality comes to notice through the fornication of god and human in the epic. The Pandavs' mother Kunti in her pre/post marital relation faces the divine compulsion for gratifying the sexual desire of sun-god who snatches her maidenhood due to her childish curiosity. Again in her spousal relation with king Pandu, she has to encounter the same plight due her husband's disability of producing children. With the consent of him, she delivers three divine sons from the cock of Dharma, Byau and Indra. This coitus of Kunti never transgresses the ethics of sexuality as this kind of sexual practice 'niyoga pratha' was in existence in some special purpose. So, the union of god and earthly woman attests the reality of sexuality.

Sexuality in Mahabharata would be treated as a part of streedharma viz. pativrata dharma. The ideology of streedharma/pativrata considers sexuality as a strategy for the psychological control of women's sexuality. The word 'pativrata' in Vedic scriptures as an adjective denotes a woman sexually faithful to her husband. It tames woman's desire, shapes and moulds it into one direction so the woman herself embraces it. It is a self-imposed demarcation for internalizing the etiquette to maintain a peaceful home. It is a way of vigilance over her psycho-somatic movement of life. The deliberate demur against it not only spreads social ignominy but also creates menace of psychological dysfunction of a wife.

The brief discussion of sexuality in Mahabharata opens up the psychological aspect of sex desire of human beings. Scientifically sexual impulsiveness in people is an inborn quality. So it is not only a womanly voraciousness but an ardent eagerness of male also. It is interesting to note that the author whenever found chances tried to establish that the intensity of sexual appeal is more violent in fair sex than in men. But it is an entire patriarchal misconception and gender obsession of the poet. He tries to overlook the issue of sages' lost of grip by visualizing the worldly damsel but exaggerate and denigrate the self-inducements of apasaras. Actually he introduces a queer theory of sexuality in which the mode of application varies or changes in accordance with the situational demand. Even the related morality also goes in parallel. Everyone specially the male world promulgates a new sex-ethics of sexual purpose for their self-interest. If sun-god invents a logic, king Pandu employs another one in favour of own argument. The defilement of Draupdi's sexual harassment at royal court certainly applauses the male voyeuristic pleasure of disrobing. Therefore, ethics and morality of sexuality in Mahabharata is nothing but a tussle. 
Wrapping up the three homogeneous topics within a single frame, one may get a clear picturesque about the status quo of women in Mahabharata. The male squad of the epic always privileged, valorized and gets much limelight than the womenfolk in terms of sexism, matrimony, purity and dharma. Right or wrong, whatever their deeds may be, poet always treats it as delinquency for male. Women only accuse in spite of their wholesome commitment to home, husband and dharma. Though a few of them showers with the poetic justice but the residual sustains the perennial minority. They stamp as arch marginalized. Though the unsung heroines of the epic purposefully have been hidden from the history, but their deeds not only reflect their existential crisis but also show the representational politics in the epical milieu. Therefore, entwining the dharma and adharma in a subtle way, the politics behind marriage and lineage of the epic discloses a new avenue for readers.

\section{References}

Bhattacharya, A.N. (1992) Dharma-Adharma and Morality in Mahabharata, Delhi: S.S. Publishers.

Bhattacharya, Dhireshchandra. (2007) Mahabharater Ekshoti Durlav Muhurto, Calcutta: Ananda Publishers Pvt. Ltd.

Brodbeck, Simon. \& Black Brian. (Ed.) (2007) Gender and Narrative in The Mahabharata, London: Routledge.

Dhand, Arti. (2004) "The Subversive Nature of Virtue in the Mahabharata: A Tale about Women, Smelly Ascetics, and God." Journal of the American Academy of Religion, vol. 72, no. 1, pp. 33-58.

Dhand, Arti. (2000) "Poison, Snake, the Sharp Edge of a Razor: Yet the Highest Gurus: Defining Female Sexuality in the Mahabharata." Diss. McGill University.

Ganguli, K.M. (Tr.) (1883-1896) The Mahabharata of Krishna-Dwaipayana Vyasa (12 volumes), New Delhi: Munshiram Manoharlal Publishers Pvt. Ltd.

Matilal, Bimal Krishna. (Ed) (1989) Moral Dilemmas in the Mahabharata, Shimla: Indian Institute of Advance Studies.

Rajneeti. (2010) Dialogue. Prakash Jha. Dir. Prakash Jha. Per. Nikhila Trikha as Bharti, Flim.

Sengupta, Poile. (2009) Women Centre Stage: The Dramatist and The Play, New Delhi: Routledge.

Shah, Shalini. (1995) The Making of Womanhood: Gender in Relations in the Mahabharata, New Delhi: Manohar Publications.

Shaw, G.B. (2004) Man and Superman: A Comedy and A Philosophy, Calcutta: Orient Longman Pvt. Ltd.

Graduated from Banaras Hindu University in the year of 2013, Dr. Biswas currently works as a Research Fellow on the project of Indology at the Asiatic Society, Kolkata. Her areas of interests are particularly Indian Feminist Theatre, Feminist Writings, Film Studies, Mahabharata Studies etc. She has authored a book and also published twelve articles in different reputed journals and books. 